\title{
ON THE SUPPOSED RAISED BEACH AT SALTBURN.
}

By G. W. Lamplugh, F.R.S.

(Read November 26th, 1919.)

The supposed presence of a Raised Beach of Post-Glacial age at Saltburn, at 35 feet above high-water mark, has afforded one of the minor problems in the geology of the Yorkshire Coast. The 'beach' was first described by Dr. W. Y. Veitch in the Proceedings of our Society for 1883 (N.S. Vol. VIII., pp. 221-6), and was referred to shortly afterwards by Mr. G. Barrow in his memoir, "The Geology of North Cleveland" (Mem. Geol. Surv., 1888, p. 71). Dr. Veitch describes the "beach' as "a band of alluvial sand containing shells and fragments of shells," of which six kinds are mentioned, all common on the present shore (Purpura, Littorina, Trochus, Lachesis minima and Cypraea europaea); and states that it was exposed in the steep driftslope below Saltburn in operations by the Saltburn Improvement Company, the deposit " extending 70 or 80 yards from the bridge up Saltburn Beck, where it abruptly comes to an end." He also found shells at about the same level "south" [east] of the beck, on the seaward slope of Cat $\mathrm{Nab}$, and considered that they indicated a continuation of the beach. Mr. Barrow gives practically the same particulars, and endorses the view that the deposit represents a Raised Beach, though he notices the abnormal circumstance that a beach of this kind should be preserved in a perishing cliff of soft Glacial beds and should be absent from the neighbouring rocky headland of Huntcliff, composed of much more durable Liassic strata.

The main reason why this 'beach' has always been questionable is that a Post-Glacial submergence of the amount implied would have inundated wide tracts of the adjacent lowland south of the Tees; and, unless the submergence were confined in a perplexing way to one small area only, the sea farther south would have entered upon the land at several places and would have extended over a large part of Holderness. But nowhere else in the coast-sections of Yorkshire has any indication of Post-Glacial submergence been found*; on the other hand, there

*In our Proceedings for 1883, in juxtaposition with Dr. Veitch's paper, there is a short note (p. 220) by the Rev. J. S. Tute on "Some Indications of a Raised Beach at Redcar," recording the occurrence of Rissoa ulva, with broken mussel and cockle shells, in sandy clay in foundations of houses at Warrenby, where the surface is stated to be about 14 feet above high-water mark. On a flat shore like that west 


\section{LAMPLUGH : ON THE SUPPOSED RAISED BEACH AT SALTBURN.}

is everywhere, both on the coast and in the interior, strong evidence that all the low ground south of the Tees (except the new land at sea level due to the accretion of warp, etc.) has been under subaerial conditions continuously from the close of the great glaciation to the present day.

With this difficulty in mind, I sought to examine the deposit some years ago when investigating the drift-sections of the coast. But the exposures seen by Dr. Veitch had been covered up, and I could make out nothing except that there was a terrace-like feature, covered with sandy soil, in the cliff of boulder-clay on the western side of the beck, where the ravine is truncated by the shore-line. From its sheltered and recessed position, however, it seemed unlikely that the terrace could have been cut by the sea.

On revisiting Saltburn in the early summer of the year 1917, I found that excavations had been made right across the terrace, and also along the sloping cliff on the opposite side of the beck, behind Old Saltburn, where Dr. Veitch found the shells that he regarded as a further indication of the 'beach.' These excavations affordei a most advantageous opportunity for examining the deposit, and this, by permission of the military authorities, I was able to do.

The excavations north and west of the 'hair-pin' bend in the road down from the Zetland Hotel to the beach and bridge were made along the north-western part of the terrace, and were continued beyond its termination in the boulder-clay slope of the outer cliff. They were about $5 \mathrm{ft}$. deep, and were for the most part entirely in sand, but touched boulder-clay at the botton at one place, and also showed the sand ending off against a sloping bank of boulder-clay where the terrace-like feature disappeared. There were no beach-pebbles in the sand, even where it was seen to rest on boulder-clay; but in one place it contained a thin streak of small bits of shale. A few weathered marine shells, mostly Littorina, were scattered among the sand, and in the upper part it contained small land shells (Helix and Pupa?). A piece of rotten wood, 3 or 4 inches long, was also noticed.

The excavations south and east of the same road, both within and to the south of the 'hair-pin' bend, revealed the structure of the remainder of the terrace, up to its southward termination in the

of Redcar, some of the lighter marine waste is always pushed above high water mark by storm-waves, and onshore winds, and its occurrence at this low level is no proof of submergence. 
slope of the ravine of Skelton Beck, just within the boundary of the pleasure-grounds. On the flat part of the terrace the continuation of the sand was seen, up to a depth of $6 \mathrm{ft}$., again with a few shells, including two species of Littorina (some being of large size), Natica, Trochus, Cardium (fragmentary), and the small land shells as before. Just under the fence of the gardens some large slabby stones, up to 8 inches in diameter, occurred half-way down in the sand, along with some smaller stones reddened by fire, the whole being suggestive of an old hearth-place. In another spot a lenticle of subangular gravelly wash, up to 9 inches thick, set in between the sand and the underlying red boulder-clay. It contained no shells and was not like a beachgravel, but resembled river-wash.

Where the terrace narrowed toward its southern termination, the sand became mixed and streaked with red loam, evidently the result of rain-wash from the neighbouring slope of boulder-clay. A more clayey rain-wash covered the slope a little farther southward, where there was no sand, and this clay-wash (which might readily be mistaken for boulder-clay in place), itself contained some large periwinkle shells, like those in the sand.

At the opposite or eastern side of the valley, the sections ran continuously along the steep slopes of the weathered cliff of drift behind Old Saltburn, at about the same level as on the western side. They were all in red boulder-clay, with here and there a patch of silt or of clayey gravel, evidently recent slope-wash, but in three or four places they crossed superficial pockets of shells of Littorina and Patella. These shell-pockets were a foot or two wide and two or three inches deep, and in one place included some bits of bone. They were clearly artificial 'kitchen-midden' heaps, and probably of no great antiquity. Heaps of limpet shells of this kind are commonly left in such situations in the recesses of the coast by fishermen in baiting their lines; but $I$ am not aware that the periwinkle is used in this way for bait. The shells noticed by Dr. Veitch on this slope are explained by the presence of these pockets, which have certainly nothing to do with a raised beach.

As regards the terrace with its sandy deposit west of the beck, I am satisfied, after seeing the sections, that this also is not a raised beach, although the feature at first sight suggests such origin. The sand has all the characteristics of a blown sand. In structure, texture and general aspect, it resembles the blown sand of adjacent slopes. 


\section{LAMPLUGH : ON THE SUPPOSED RAISED BEACH AT SALTBURN.}

The coast from Saltburn to Redcar is exposed to all winds between north-west and north-east, and at low tide these winds cross broad tracts of bare sand before reaching the eliff, with the result that sand is driven up far above high-water mark on the lower slopes of any crumbling bank of drift that fronts the shore. Even where the cliff. rises well over the $100 \mathrm{ft}$. contour, north-west of the Hazel Grove ravine, its sloping portions are veneered quite to the top with blown sand.

The presence of sporadic marine shells in the sand of the terrace is no proof that it is an old beach. The smaller shells-Lachesis and Cypraea - are of kinds readily blown by the wind, while the heavier shells are such as may have been distributed by sea-birds and by man, whose agency is clearly indicated by the burnt stones mentioned above. Anyone who has scrambled about on the steep grassy slopes that front the sea in many of the little bays of the Yorkshire coast will remember how common it is to find accidentally transported shells and shell-fragments upon them, and, in consequence, how careful one has to be, in searching for shells in the drift deposits, to distinguish between these and the true drift-shells. The fact that some shells similar to those in the supposed beach-sand are present also in the clayey rain-wash of the slope, as I have mentioned in describing the sections, is further evidence for the accidental distribution of the shells; and the 'shell-pockets' on the Old Saltburn slope were seen to be, beyond doubt, artificial.

The terrace-feature which has perhaps afforded hitherto the most generally-accepted presumptive evidence for the supposed beach remains to be dealt with; and I think that it can be very simply and satisfactorily explained. It is almost certainly an old erosion-terrace of Skelton Beck, before the ravine was cut down to its present level and when its mouth lay to the seaward of its present position. Below the point, over half a mile inland, where the beck leaves a narrow rockgorge, a wide trough has been carved entirely in the Glacial drifts ; and all along this trough (now the picturesque Pleasure Grounds of Saltburn) there are remnants of old erosion-flats, here and there at various levels, marking stages of the down-cutting. Close to its present mouth the valley expands, owing to the confluence of two small streams on the eastern side, which have cut the deep gullies in drift known respectively as Saltburn Gill and Little Dale. As is usual under such conditions, the terracing of the main valley has been accentuated around the confluence; and the small embayment on the 
western side, which carries the supposed raised beach, occurs just where the main stream is likely to have been driven against the western slope by the agency of its eastern tributaries. If it be recognized, as I think it must, that the platform has had its origin as a river-terrace, all difficulties as to its position disappear ; and there is seen to be a corresponding feature at about the same level on the opposite side of the valley, on the spur between the main beck and its chief tributary. The fluviatile aspect of the patch of gravelly wash seen beneath the sand in the recent cuttings on the terrace lends further support to my opinion that the platform has not been cut by the sea, but by the beck.

At the time that the terrace was formed it would, of course, be well within the valley, which must then have extended some distance farther northward than now before reaching the sea. The drift-cliffs up to the setting in of the solid Liassic rocks east of Old Saltburn show every indication of steadily wasting land, and the encroachment of the sea must have been in progress here until it was checked by the artificial defence-works. The persistence of the terrace-feature on this wasting coast, on the supposition that it was an ancient beach, was always difficult to account for, but if considered as a feature belonging to the valley, there is no difficulty.

Other supporting arguments against the 'beach' origin might be brought forward, but it seems unnecessary to labour the discussion further. I think that we need no longer take this awkward and anomalous 'Raised Beach' into our reckoning in dealing with the Post-Glacial history of the Yorkshire coast-lands.

In conclusion I may mention that the examples of former streamdiversion on a small scale, which cause the irregularity of the ridges between the confluent streams and the cliff-front, are probably due to the readjustment of the drainage-gradients between the main stream and its tributaries, consequent upon the shortening of the principal valley by the encroachment of the sea. The features afford an instructive physiographical study in miniature. 